Article

\title{
Does High Voltage Electrical Discharge Treatment Induce Changes in Tannin and Fiber Properties of Cocoa Shell?
}

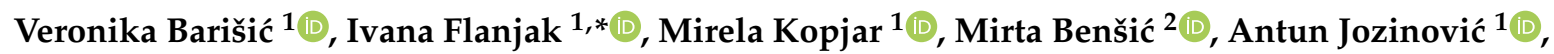 \\ Jurislav Babić ${ }^{1}$, Drago Šubarić ${ }^{1}$ (D), Borislav Miličević ${ }^{1,3}$, Kristina Doko ${ }^{4}$, Midhat Jašić ${ }^{5}$ and \\ Đurđica Ačkar ${ }^{1}$ (D) \\ 1 Faculty of Food Technology Osijek, Josip Juraj Strossmayer University of Osijek, Franje Kuhača 18, \\ 31000 Osijek, Croatia; veronika.barisic@ptfos.hr (V.B.); mirela.kopjar@ptfos.hr (M.K.); \\ antun.jozinovic@ptfos.hr (A.J.); jurislav.babic@ptfos.hr (J.B.); drago.subaric@ptfos.hr (D.Š.); \\ bmilicevic@ptfos.hr (B.M.); dackar@ptfos.hr (Đ.A.) \\ 2 Department of Mathematics, Josip Juraj Strossmayer University of Osijek, Trg Ljudevita Gaja 6, \\ 31000 Osijek, Croatia; mirta@mathos.hr \\ 3 Polytechnic in Požega, Vukovarska 17, 34000 Požega, Croatia \\ 4 Federal Agro Mediterranean Institute, Biskupa Čule 10, 88000 Mostar, Bosnia and Herzegovina; \\ kristina.skender@gmail.com \\ 5 Faculty of Technology Tuzla, Univerzitetska 8, 75000 Tuzla, Bosnia and Herzegovina; \\ jasic_midhat@yahoo.com \\ * Correspondence: ivana.flanjak@ptfos.hr
}

Received: 4 June 2020; Accepted: 18 June 2020; Published: 19 June 2020

\begin{abstract}
Cocoa shell is a by-product of the chocolate industry that is rich in dietary fiber and bioactive components. In this research, the influence of high voltage electric discharge (HVED) treatment on chemical and physical characteristics of the cocoa shell, i.e., the effects of applied time and frequencies on grinding ability, water binding capacity (WBC), dietary fibers and tannin content was investigated. HVED had a significant influence on the chemical and physical properties of cocoa shell, all of which could be linked to changes in fiber properties. Along with the fiber content, grinding ability and water binding capacity were increased. These properties have already been linked to fiber content and soluble/insoluble fiber ratio. However, this research implies that change in fiber properties could be linked to tannin formation via complexation of other polyphenolic components. Additional research is needed to verify this effect and to establish mechanisms of tannin formation induced by HVED and its influence on fiber quantification.
\end{abstract}

Keywords: cocoa shell; high voltage electrical discharge; tannin; dietary fiber; water binding capacity; grindability

\section{Introduction}

Cocoa shell is the major by-product of the cocoa processing industry. It is a part of the cocoa bean that is separated from cotyledon during pre-roasting or after the roasting of beans [1]. It has been reported that several tons of cocoa shell need to be disposed annually, which poses a large problem [2,3]. Cocoa beans are rich in bioactive compounds, which are stored in the cotyledon. During fermentation, these components diffuse into cocoa shell, which becomes rich in bioactive compounds [4]. In addition, cocoa shell is rich in dietary fiber, mainly consisting of cellulose, carbohydrates and pectic polysaccharides [2] and presents great material for use in food industry and enrichment of food poor in dietary fibers. In the last few years, cocoa shell has been used as a raw biomass material, feedstuff, adsorbent, soil conditioner, garden mulch or burnt for fuel $[5,6]$. 
High voltage electric discharge (HVED) is a non-thermal process that has been used for the treatment of waste products from the food industry in the last few years [7]. It is also used as an extraction method, because it can disrupt the cellular walls and increase the overall mass transfer of the cellular content [8]. HVED is an innovative technique that interjects energy directly in aqueous solution between electrodes that are submerged. Electric discharge in water consists of two phases: corona streamer discharge process and arc discharge process. For the streamer discharge process weak shock waves are characteristic, as well as small number of bubbles and active radicals. When transiting to arc discharge process, number of bubbles is increased, shock waves become stronger, turbulence and concentration of free radicals are increased [9]. These shock waves and explosions of cavitation bubbles can affect particle size by fragmentation of cell membranes [10]. Electric discharge directly in water leads to production of molecular oxygen and hydrogen, hydrogen peroxide, hydroxyl radicals and oxygen radical ion, all of which are very reactive species.

Since HVED can disrupt cellular walls, which are in cocoa shell predominantly composed of cellulose with lesser amounts of hemicellulose and pectin [3], the aim of this study was to evaluate HVED influence on cocoa shell dietary fiber content and properties related to it. For use of cocoa shell in food industry, dietary fiber content, grindability, water and oil binding capacity and content of bioactive components are very important.

\section{Materials and Methods}

\subsection{Preparation of Cocoa Shell}

Cocoa shell samples were obtained after roasting fermented cocoa beans (West Africa mix supplied by Huyser, Möller B.V., Edam, Holland) at $135^{\circ} \mathrm{C}$ for $55 \mathrm{~min}$ in custom made roaster (Metal workshop "ILMA", Požega, Croatia). After that, the cocoa shell was easily separated by hand from the cotyledon.

Untreated cocoa shell (UCS) sample was obtained by grinding cocoa shell attained after separation from the cotyledon. Control samples were obtained by mixing the unmilled cocoa shell in water for 15, 30 and $45 \mathrm{~min}$ at concentrations of $1.5 \%$ and $3.0 \%$. After mixing, the shell was separated from water and dried in the laboratory oven (Memmert, UFE 500, Schwabach, Germany) at $40{ }^{\circ} \mathrm{C}$. Dry samples were ground in the laboratory mill (IKA, M20, Staufen, Germany) (25 g for 2 min with cooling) to obtain a fine powder (composite sample obtained by repeated grinding) and as such were frozen and stored for analyses. The grinded untreated cocoa shell was also frozen and stored for analysis in the same way as a cocoa shell mixed in water.

\subsection{HVED Treatment}

High-voltage electrical discharge equipment which was described by Barišić et al. [11] includes a chamber connected to a high-voltage pulse generator of $30 \mathrm{kV}$ (the device was custom made by Inganiare CPTS1, Osijek, Croatia for the Faculty of Food Technology Osijek). Treatment chamber contains a stainless steel cylindrical needle (diameter $2.5 \mathrm{~mm}$ ), and the ground electrode in the form of a plate (diameter $45 \mathrm{~mm}$ ). Mixing of samples is achieved by magnetic stirrer. The distance between the electrodes during all treatments was $2 \mathrm{~cm}$. Electric field density was $15 \mathrm{kV} / \mathrm{cm}$ during all treatments. HVED energy input ranged between $13.11-79.80 \mathrm{~kJ} / \mathrm{kg}$.

Unmilled cocoa shell (same as control samples prepared in water) was treated in HVED device at concentrations of $1.5 \%$ (6 g in $400 \mathrm{~mL}$ of distilled water) and 3.0\% (12 g in $400 \mathrm{~mL}$ of distilled water). The treatment time was 15, 30 and $45 \mathrm{~min}$, and the used frequencies were 40 and $80 \mathrm{~Hz}$. Each sample (HVED, control or untreated) was treated until $200 \mathrm{~g}$ of sample was gained which gave us uniform sample for all analyses. The cocoa shell treated with HVED was dried, grind and stored until analyses in the same way as the control samples. Control samples (mixed in water) and HVED treated samples were dried to a dry matter content of $86.00 \pm 0.85 \%$. 


\subsection{Tannin Content}

\subsubsection{Extraction}

Each sample was weighed $(2 \mathrm{~g})$ and extracted three times with $10 \mathrm{~mL}$ of $n$-hexane (Carlo Erba Reagents, Val de Reuil, France) to remove lipids. Samples were dried at air over night and extracted with $5 \mathrm{~mL} 70 \%$ methanol (J. T. Baker, Deventer, Netherland) in ultrasound bath. After that, samples were centrifuged for $10 \mathrm{~min}$ at $3000 \mathrm{rpm}$ (Sigma 2-16, Sigma, Osterode, Germany). Supernatant was decanted in $10 \mathrm{~mL}$ volumetric flask. That procedure was repeated twice after which flask with supernatant was filled up with $70 \%$ methanol.

\subsubsection{Spectrophotometric Analysis}

Tannin content was determined by method described by Amorim et al. [12]. Method is based on binding of tannins with casein. Calibration curve was created with the standard solutions of tannic acid (Sigma-Aldrich, St. Louis, USA) in the range of concentrations from 0.5 to $3 \mathrm{mg} / \mathrm{mL}$ $\left(\mathrm{y}=0.9011 \mathrm{x}+0.0095 ; R^{2}=0.9993\right)$. Total phenol content and residual phenol content (obtained after complexation of tannin and casein) were determined spectrophotometrically at $760 \mathrm{~nm}$ according to the method of Singleton et al. [13]. Tannin content in prepared extracts was calculated Equation (1) as the difference between total phenol content and residual phenol content. Results are presented as $\mathrm{mg}$ of tannic acid per $\mathrm{g}$ of defatted sample (mg TA/g) and as a percentage of tannin in total phenol content $(\%)$.

$$
\text { Tannin }\left(\frac{\mathrm{mg} \text { TA }}{\mathrm{g}}\right)=\text { total phenol content }- \text { residual phenol content }
$$

\subsection{Determination of Dietary Fibers}

Dietary fibers were determined according to gravimetric AOAC method 991.43 [14]. Samples were treated with thermostable $\alpha$-amylase, protease and amyloglucosidase (Megazyme Total Dietary Fiber Assay Kit, Megazyme Ltd., Bray, Ireland). The share of insoluble dietary fibers (IDF, \%) was determined gravimetrically after filtration, and soluble dietary fibers (SDF, \%) were determined by precipitation from the obtained filtrate. After correction for undigested protein (Kjeldahl method) and ash (mineralization at $525^{\circ} \mathrm{C}$ ), total dietary fibers were calculated Equations (2) and (3) as a sum of IDF and SDF. The values were calculated on the dry matter of the sample.

$$
\begin{gathered}
\text { Total Dietary Fibre }(\%)=\frac{\frac{\mathrm{R}_{1}+\mathrm{R}_{2}}{2}-\mathrm{p}-\mathrm{A}-\mathrm{B}}{\frac{\mathrm{m}_{1+} \mathrm{m}_{2}}{2}} \times 100 \\
\mathrm{~B}=\frac{\mathrm{BR}_{1}+\mathrm{BR}_{2}}{2}-\mathrm{BP}-\mathrm{BA}
\end{gathered}
$$

where: $\mathrm{R}_{1}=$ residue weight 1 from $\mathrm{m}_{1} ; \mathrm{R}_{2}=$ residue weight 2 from $\mathrm{m}_{2} ; \mathrm{m}_{1}=$ sample weight 1 ; $\mathrm{m}_{2}=$ sample weight $2 ; \mathrm{A}=$ ash weight from $\mathrm{R}_{1} ; \mathrm{P}=$ protein weight from $\mathrm{R}_{2} ; \mathrm{B}=$ blank; $\mathrm{BR}=$ blank residue; $\mathrm{BP}=$ blank protein from $\mathrm{BR}_{1} ; \mathrm{BA}=$ blank ash from $\mathrm{BR}_{2}$.

\subsection{Grindability of Cocoa Shell}

The grindability of cocoa shell was determined by sieving the powdered cocoa shell samples on analytical sieve shaker (Retsch GmbH, AS200, Haan, Germany) and measurement of mass of obtained fractions. A total of $50 \mathrm{~g}$ of the sample was sieved through six sieves (50, 71, 100, 125, 200 and $315 \mu \mathrm{m})$ during $15 \mathrm{~min}$. After weighing each fraction, results were expressed as percentages of cocoa shell mass that was weighted on each sieve (\%). 


\subsection{Water Binding Capacity (WBC) and Oil Binding Capacity (OBC)}

For determination of WBC standard AACC Method 88-04 [15], was used. To $2.5 \mathrm{~g}$ of cocoa shell sample $30 \mathrm{~mL}$ of water was added. These solutions were left to stand at room temperature with periodic mixing. After that, the samples were centrifuged at $3000 \mathrm{rpm}$ for $15 \mathrm{~min}$ (Centra-MP4R, IEC, Mumbai, India). The supernatant was decanted, and the remaining residue was weighted. The analysis was performed in two repetitions. The results were calculated Equation (4) and were expressed as grams of $\mathrm{H}_{2} \mathrm{O}$ absorbed per gram of cocoa shell $(\mathrm{g} / \mathrm{g})$.

$$
\mathrm{WBC}\left(\frac{\mathrm{g}}{\mathrm{g}}\right)=\frac{\text { gel mass }}{\text { dry matter mass in the initial sample }}
$$

For determination of $\mathrm{OBC}$ same procedure was used. The only difference was that for OBC instead of water cold pressed rapeseed oil was used. Results were expressed as grams of oil absorbed per gram of cocoa shell (\%) obtained by formula Equation (5):

$$
\mathrm{OBC}\left(\frac{\mathrm{g}}{\mathrm{g}}\right)=\frac{\text { gel mass }}{\text { dry matter mass in the initial sample }}
$$

\subsection{Fourier Transform Infrared Spectroscopy with Attenuated Total Reflection (FTIR-ATR) Analysis}

FTIR-ATR spectra were recorded with a Cary 630 spectrometer (Agilent, Santa Clara, CA, USA) in wavenumber range from 4000 to $650 \mathrm{~cm}^{-1}$. For each sample, 32 scans were recorded and averaged with a spectral resolution of $16 \mathrm{~cm}^{-1}$.

\subsection{Statistical Analysis}

Statistical analysis was conducted using Statistica ${ }^{\circledR}$, Version 13.4.0.14 (1984-2018 TIBCO Software Inc, Palo Alto, CA, USA). To determine the statistically significant difference of treatment effects, main effects and factorial analysis of variance (ANOVA) were used. P-value that was considered significant was 0.05. In addition, Pearson's correlation coefficients was determined $(p<0.05)$.

\section{Results and Discussion}

\subsection{Tannin Content}

Tannin content of untreated cocoa shell and treated samples are shown in Figure 1 where results for tannin content (mg TA/g of defatted sample) and percentages of tannins in total phenols (\%) are presented. It can be seen that the untreated shell had the lowest content of tannins, and the tannin content increased with all treatments. In samples treated with HVED, share of tannins in total phenols ranged from 45.03 to $65.09 \%$. In our previous research [16], we have measured the decrease of content of all major polyphenolic compounds in cocoa shell treated with HVED (catechin, epicatechin, epicatechin gallate, gallic acid, caffeic acid and $p$-coumaric acid). These components are extractable by water, and the decrease in treated shell may have been the consequence of extraction, as reported by Jokić et al. [17], however, they are also prone to reactions of condensation in suitable conditions (Figure 2). Since the aim of this study was not to establish the effect of HVED treatment on extraction of bioactive compounds, cocoa shell was not milled before treatment, unlike in research of Jokić et al. [17]. Extraction yield is also dependent on electric field intensity, contact surface between material and solvent, liquid to solid ratio, etc. Considering above mentioned, HVED conditions applied in this research are not favorable for extraction [9]. Thus, extraction of polyphenolic compounds was aggravated. HVED generates different reactive species, which may have induced polymerization. Hence, HVED is a source of radicals that can easily oxidize tannins, which leads to an increase in their rigidity. Contrary to our results, Delsart et al. [18] and Lukić et al. [19] reported decrease of total tannin content in red wine treated by HVED and cold plasma, respectively, ascribing it to oxidation of tannins during treatment. 
However, one has to bear in mind that cold plasma and HVED treatment differ in that cold plasma includes gas introduction into liquid, and that there are major differences in chemical composition, mainly polyphenolic profile, of the treated samples. In addition, since treatment time in this research was significantly longer, oxidized tannins and other phenols might have been involved in mutual reactions, mainly because the oxidized phenols are hydrophobic. It has been reported that hydrophobic reactions can occur among polyphenols and induce their aggregation [20].
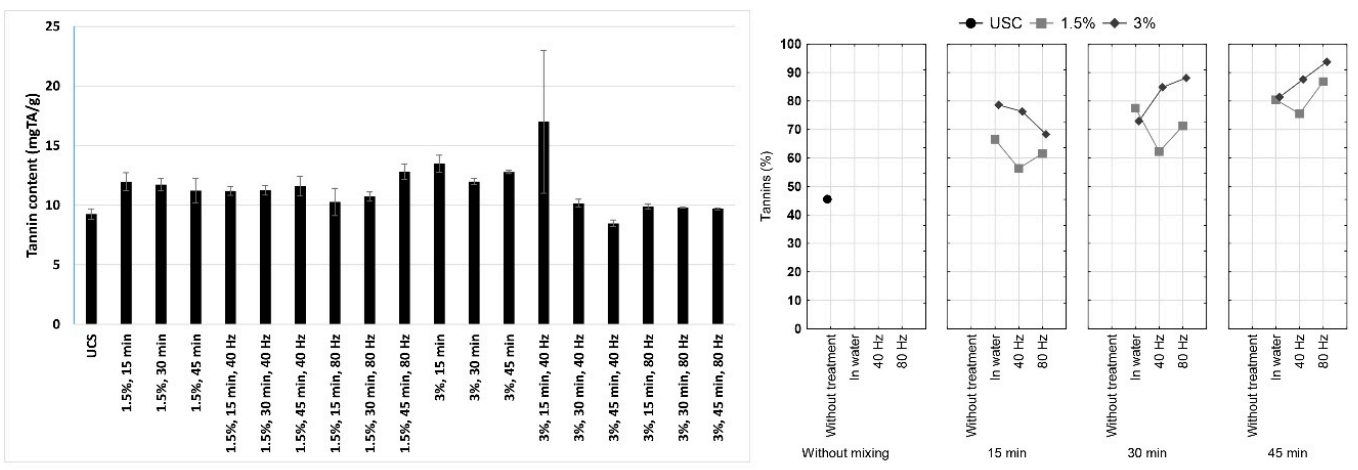

Figure 1. Tannin content (expressed on defatted sample weight) in cocoa shell before and after the high voltage electric discharge (HVED) treatment and percent of tannin in total phenols.

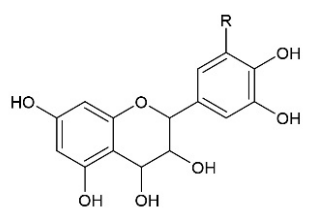

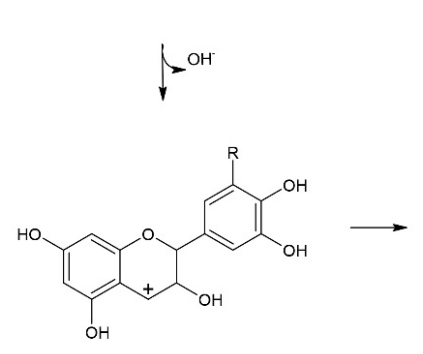

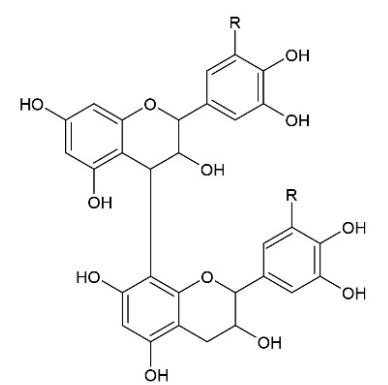

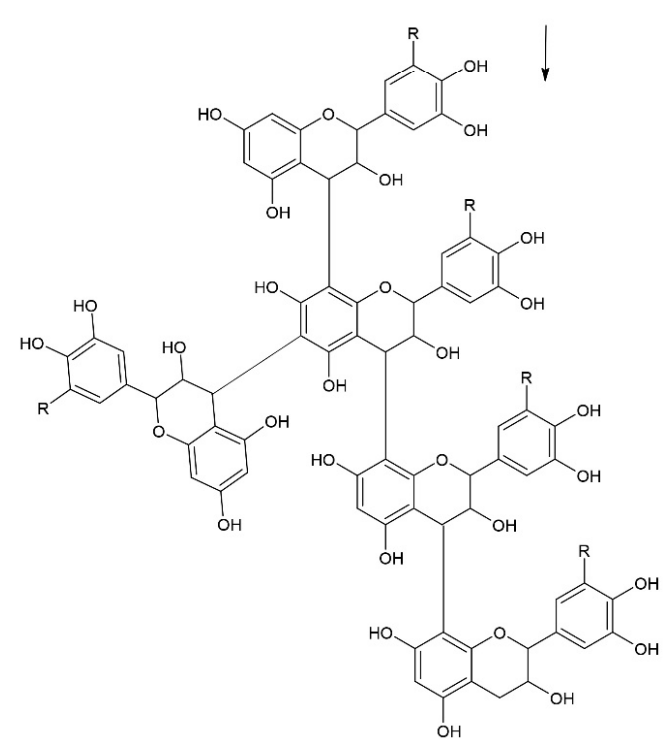

Figure 2. Condensation of polyphenols. 
Results of tannin content, both in sample and in total phenols show that tannins are very resistant to HVED treatment. With the exception of 3.0\% sample treated at $40 \mathrm{~Hz}$, where significant reduction of tannin content occurred with the increase of treatment time, a slight increase of their content after treatment was observed (Figure 1), possibly due to oxidation and aggregation of tannins, but also due to the loss of a portion of soluble substances during treatment, which led to a change in the ratio of components in the samples.

Statistical analysis confirmed that tannins are very resistant to HVED treatment, since statistical significance was not established. Furthermore, factorial analysis of variance showed that influence of concentration and mixing time on percent of tannin in total phenols is statistically significant (Table 1). Coefficient of correlation is showing that tannin (\%) is in relation with the smallest and largest particles, insoluble and total fibers. This may indicate that tannins have an impact on the proportion of fibers in cocoa shells, since the content of insoluble and total fibers increase as the proportion of tannin increases.

Table 1. Factorial analysis of variance.

\begin{tabular}{|c|c|c|c|c|c|c|}
\hline & & Sum of Squares & DF & Mean Square & F-Value & $p$-Value \\
\hline \multirow{9}{*}{ OBC (g/g) } & Intercept & 392.4578 & 1 & 392.4578 & $533,103.9$ & $<0.001 *$ \\
\hline & Concentration (C) & 0.2885 & 1 & 0.2885 & 391.8 & $<0.001 *$ \\
\hline & Mixing $(\mathrm{M})$ & 0.1274 & 2 & 0.0637 & 86.5 & $<0.001 *$ \\
\hline & Treatment (T) & 0.1614 & 2 & 0.0807 & 109.6 & $<0.001 *$ \\
\hline & $\mathrm{C}^{*} \mathrm{M}$ & 0.0200 & 2 & 0.0100 & 13.6 & $<0.001^{*}$ \\
\hline & $\mathrm{C}^{*} \mathrm{~T}$ & 0.0474 & 2 & 0.0237 & 32.2 & $<0.001 *$ \\
\hline & $\mathrm{M}^{*} \mathrm{~T}$ & 0.0516 & 4 & 0.0129 & 17.5 & $<0.001 *$ \\
\hline & $\mathrm{C}^{*} \mathrm{M}^{*} \mathrm{~T}$ & 0.0821 & 4 & 0.0205 & 27.9 & $<0.001 *$ \\
\hline & Error & 0.0133 & 18 & 0.0007 & & \\
\hline \multirow{9}{*}{ WBC (g/g) } & Intercept & 2384.278 & 1 & 2384.278 & $313,752.4$ & $<0.001^{*}$ \\
\hline & Concentration (C) & 15.149 & 1 & 15.149 & 1993.6 & $<0.001^{*}$ \\
\hline & Mixing $(\mathrm{M})$ & 3.762 & 2 & 1.881 & 247.6 & $<0.001 *$ \\
\hline & Treatment (T) & 0.040 & 2 & 0.020 & 2.6 & 0.101638 \\
\hline & $\mathrm{C}^{*} \mathrm{M}$ & 0.130 & 2 & 0.065 & 8.5 & 0.002470 * \\
\hline & $\mathrm{C}^{*} \mathrm{~T}$ & 0.177 & 2 & 0.088 & 11.6 & $<0.001 *$ \\
\hline & $\mathrm{M}^{*} \mathrm{~T}$ & 0.266 & 4 & 0.066 & 8.8 & $<0.001 *$ \\
\hline & $\mathrm{C}^{*} \mathrm{M}^{*} \mathrm{~T}$ & 0.516 & 4 & 0.129 & 17.0 & $<0.001 *$ \\
\hline & Error & 0.137 & 18 & 0.008 & & \\
\hline \multirow{9}{*}{$\begin{array}{c}\text { Tannin (mg TA/g of } \\
\text { defatted sample) }\end{array}$} & Intercept & 4714.410 & 1 & 4714.410 & 1021.198 & $<0.001$ * \\
\hline & Concentration $(\mathrm{C})$ & 0.030 & 1 & 0.030 & 0.006 & 0.936726 \\
\hline & Mixing (M) & 13.343 & 2 & 6.671 & 1.445 & 0.261805 \\
\hline & Treatment $(\mathrm{T})$ & 17.066 & 2 & 8.533 & 1.848 & 0.186168 \\
\hline & $\mathrm{C}^{*} \mathrm{M}$ & 24.240 & 2 & 12.120 & 2.625 & 0.099895 \\
\hline & $\mathrm{C}^{*} \mathrm{~T}$ & 10.946 & 2 & 5.473 & 1.186 & 0.328333 \\
\hline & $\mathrm{M}^{*} \mathrm{~T}$ & 29.441 & 4 & 7.360 & 1.594 & 0.218875 \\
\hline & $\mathrm{C}^{*} \mathrm{M}^{*} \mathrm{~T}$ & 24.668 & 4 & 6.167 & 1.336 & 0.294923 \\
\hline & Error & 83.098 & 18 & 4.617 & & \\
\hline \multirow{9}{*}{$\begin{array}{c}\text { Tannin (\% of } \\
\text { total polyphenols) }\end{array}$} & Intercept & $114,239.9$ & 1 & $114,239.9$ & 3614.463 & $<0.001$ * \\
\hline & Concentration (C) & 202.5 & 1 & 202.5 & 6.406 & 0.020914 * \\
\hline & Mixing (M) & 453.1 & 2 & 226.5 & 7.167 & 0.005134 * \\
\hline & Treatment $(\mathrm{T})$ & 84.5 & 2 & 42.3 & 1.337 & 0.287391 \\
\hline & $\mathrm{C}^{*} \mathrm{M}$ & 75.8 & 2 & 37.9 & 1.200 & 0.324306 \\
\hline & $\mathrm{C}^{*} \mathrm{~T}$ & 49.7 & 2 & 24.9 & 0.786 & 0.470508 \\
\hline & $\mathrm{M}^{*} \mathrm{~T}$ & 146.0 & 4 & 36.5 & 1.155 & 0.363192 \\
\hline & $\mathrm{C}^{*} \mathrm{M}^{*} \mathrm{~T}$ & 102.3 & 4 & 25.6 & 0.809 & 0.535434 \\
\hline & Error & 568.9 & 18 & 31.6 & & \\
\hline
\end{tabular}

OBC: oil binding capacity; WBC: water binding capacity; DF: degree of freedom; ${ }^{*} p<0.05$ statistically significant.

\subsection{Dietary Fibers}

Proportions of soluble, insoluble and total fibers of cocoa shell samples are shown in Figure 3. It can be seen that content of insoluble and total fibers in treated samples is higher than in untreated cocoa shell. The effect of HVED on soluble dietary fibers was not statistically significant (Table 2). An increase of insoluble fiber share after treatment had statistical significance for mixing time and there is a visible trend. A greater effect on increase of insoluble fiber content was in HVED treated samples at $1.5 \%$ concentration than at $3.0 \%$ due to greater energy input at lower sample concentration. 


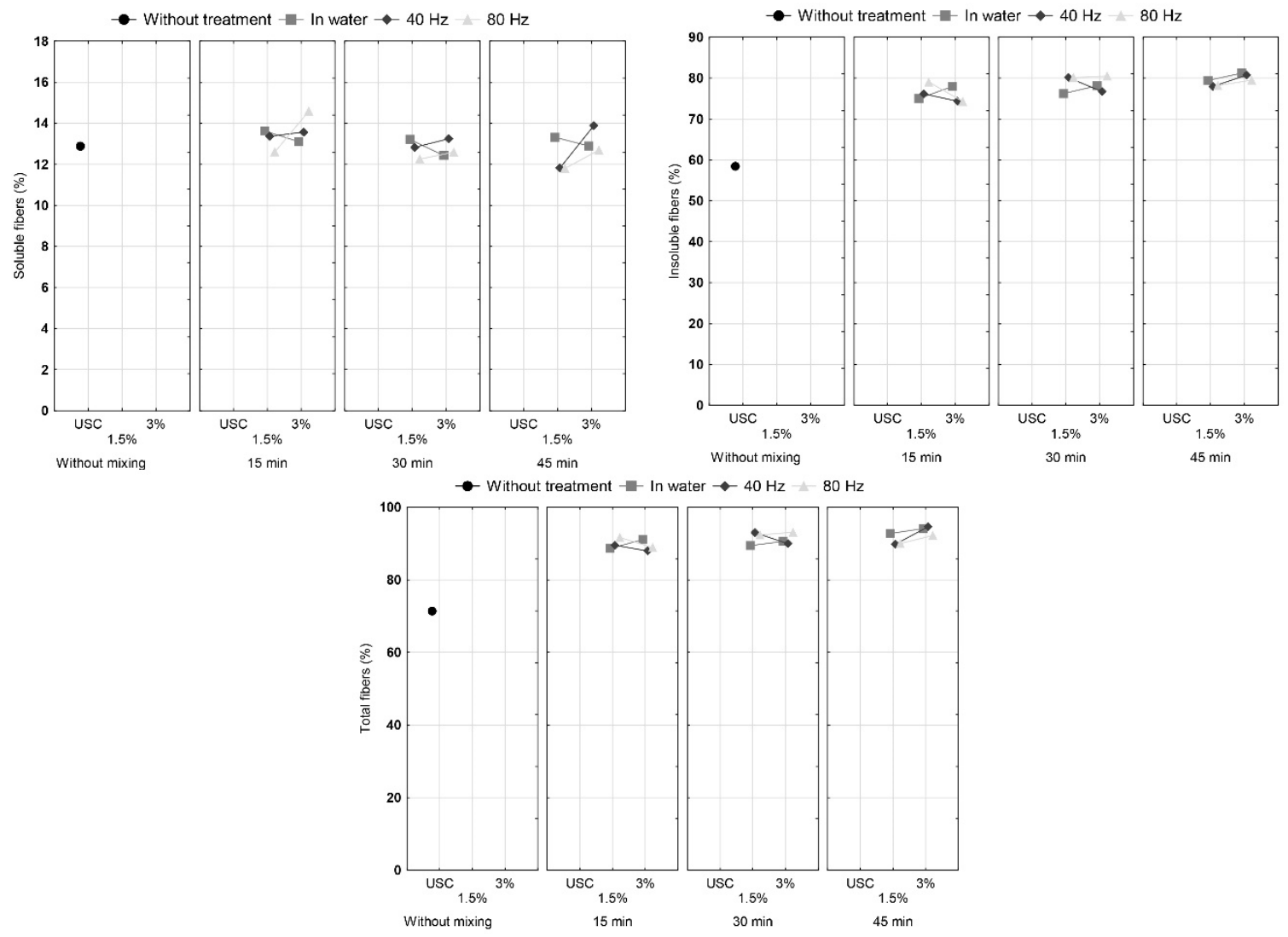

Figure 3. Content of insoluble, soluble and total fibers in cocoa shell before and after the HVED treatment.

Increasing the fiber content in treated cocoa shells can be explained by the fact that during various treatments, fiber probably bonded with other components of the cocoa shell. However, some researches have shown that results obtained by gravimetric determination of fiber may be increased due to presence of insoluble proteins and condensed tannins [21-23]. The method used in this research has a step to exclude undigested proteins from the results for fiber content, however, condensed tannins may have an effect on the observed increase.

Condensed tannins are, along with resistant protein and Maillard reaction products, part of so-called Klason lignin [21], which is not always considered as a fiber. As shown by Perez et al. [24], roasted husk contains large amounts of free amino-acids and sugars, and our previous research [16] showed significant amounts of catechins. HVED generates free radicals and charged particles and highly reactive species $\left(\mathrm{H}^{+}, \mathrm{OH}^{-}, \mathrm{H}_{2} \mathrm{O}_{2}\right)$, which may have induced advanced Maillard reactions and reactions of condensation of catechins to condensed tannins (Figure 2).

Our previous research showed that most likely 5-HMF and acrylamide are reacting with free radicals created by HVED and generating new compounds, which could be a part of Klason lignin [25]. This could contribute to increase of insoluble dietary fibers especially because condensed tannins and products of advanced Maillard reactions are insoluble in water.

In addition, we noticed that HVED treated samples had more undigested proteins than non-treated samples (results not shown). Decreased digestibility of proteins can be result of complex formation with tannins especially because HVED treatment generates change in $\mathrm{pH}$ and surface charge, which could be favorable conditions for complexation. Reduced in vitro and in vivo digestibility of proteins due to formation of complexes with tannins has already been reported for sorghum and several Acacia species. In addition, protein-protein complexation induced by tannins, and enzyme inhibition by tannins were also reported [26]. Although corrections for proteins were made, the other components that were bonded to them were not included here. 
Table 2. Main effects analysis of variance.

\begin{tabular}{|c|c|c|c|c|c|c|}
\hline & Effect & Sum of Squares & DF & Mean Square & F-Value & $p$-Value \\
\hline \multirow{5}{*}{$0-50 \mu \mathrm{m}$} & Intercept & 169.1845 & 1 & 169.1845 & 59.27547 & $0.000006^{*}$ \\
\hline & Concentration & 20.7446 & 1 & 20.7446 & 7.26806 & 0.019455 * \\
\hline & Mixing & 2.4918 & 2 & 1.2459 & 0.43652 & 0.656146 \\
\hline & Treatment & 2.8862 & 2 & 1.4431 & 0.50561 & 0.615433 \\
\hline & Error & 34.2505 & 12 & 2.8542 & & \\
\hline \multirow{5}{*}{$51-71 \mu \mathrm{m}$} & Intercept & 2025.733 & 1 & 2025.733 & 451.2232 & $<0.001 *$ \\
\hline & Concentration & 54.266 & 1 & 54.266 & 12.0875 & 0.004574 * \\
\hline & Mixing & 12.171 & 2 & 6.085 & 1.3555 & 0.294609 \\
\hline & Treatment & 1.952 & 2 & 0.976 & 0.2174 & 0.807671 \\
\hline & Error & 53.873 & 12 & 4.489 & & \\
\hline \multirow{5}{*}{$72-100 \mu \mathrm{m}$} & Intercept & 1371.127 & 1 & 1371.127 & 705.1271 & $<0.001 *$ \\
\hline & Concentration & 18.601 & 1 & 18.601 & 9.5659 & 0.009312 * \\
\hline & Mixing & 0.303 & 2 & 0.152 & 0.0780 & 0.925440 \\
\hline & Treatment & 1.729 & 2 & 0.864 & 0.4446 & 0.651247 \\
\hline & Error & 23.334 & 12 & 1.945 & & \\
\hline \multirow{5}{*}{$101-125 \mu \mathrm{m}$} & Intercept & 525.4466 & 1 & 525.4466 & 970.2258 & $<0.001 *$ \\
\hline & Concentration & 0.9016 & 1 & 0.9016 & 1.6648 & 0.221262 \\
\hline & Mixing & 0.5083 & 2 & 0.2542 & 0.4693 & 0.636443 \\
\hline & Treatment & 0.8918 & 2 & 0.4459 & 0.8234 & 0.462285 \\
\hline & Error & 6.4989 & 12 & 0.5416 & & \\
\hline \multirow{5}{*}{$126-200 \mu \mathrm{m}$} & Intercept & 3189.472 & 1 & 3189.472 & 1644.420 & $<0.001 *$ \\
\hline & Concentration & 1.189 & 1 & 1.189 & 0.613 & 0.448736 \\
\hline & Mixing & 2.527 & 2 & 1.264 & 0.651 & 0.538775 \\
\hline & Treatment & 2.636 & 2 & 1.318 & 0.679 & 0.525389 \\
\hline & Error & 23.275 & 12 & 1.940 & & \\
\hline \multirow{5}{*}{$201-315 \mu \mathrm{m}$} & Intercept & 5128.784 & 1 & 5128.784 & 3745.356 & $<0.001 *$ \\
\hline & Concentration & 0.147 & 1 & 0.147 & 0.107 & 0.748864 \\
\hline & Mixing & 3.778 & 2 & 1.889 & 1.379 & 0.288933 \\
\hline & Treatment & 4.432 & 2 & 2.216 & 1.618 & 0.238628 \\
\hline & Error & 16.432 & 12 & 1.369 & & \\
\hline \multirow{5}{*}{$>315 \mu \mathrm{m}$} & Intercept & $31,757.57$ & 1 & $31,757.57$ & 1505.873 & $<0.001 *$ \\
\hline & Concentration & 26.88 & 1 & 26.88 & 1.275 & 0.280959 \\
\hline & Mixing & 45.68 & 2 & 22.84 & 1.083 & 0.369462 \\
\hline & Treatment & 52.88 & 2 & 26.44 & 1.254 & 0.320301 \\
\hline & Error & 253.07 & 12 & 21.09 & & \\
\hline \multirow{5}{*}{$\begin{array}{l}\text { Insoluble } \\
\text { fibers }\end{array}$} & Intercept & $109,774.9$ & 1 & $109,774.9$ & $30,704.36$ & $<0.001$ \\
\hline & Concentration & 0.1 & 1 & 0.1 & 0.02 & 0.883234 \\
\hline & Mixing & 36.8 & 2 & 18.4 & 5.15 & 0.024326 * \\
\hline & Treatment & 2.7 & 2 & 1.4 & 0.38 & 0.691002 \\
\hline & Error & 42.9 & 12 & 3.6 & & \\
\hline \multirow{5}{*}{$\begin{array}{l}\text { Soluble } \\
\text { fibers }\end{array}$} & Intercept & 3038.191 & 1 & 3038.191 & 7378.913 & $<0.001 *$ \\
\hline & Concentration & 0.962 & 1 & 0.962 & 2.336 & 0.152303 \\
\hline & Mixing & 2.116 & 2 & 1.058 & 2.570 & 0.117785 \\
\hline & Treatment & 0.501 & 2 & 0.250 & 0.608 & 0.560488 \\
\hline & Error & 4.941 & 12 & 0.412 & & \\
\hline \multirow{5}{*}{ Total fibers } & Intercept & $149,338.0$ & 1 & $149,338.0$ & $43,452.47$ & $<0.001 *$ \\
\hline & Concentration & 1.6 & 1 & 1.6 & 0.47 & 0.508137 \\
\hline & Mixing & 21.7 & 2 & 10.9 & 3.16 & 0.079032 \\
\hline & Treatment & 1.0 & 2 & 0.5 & 0.14 & 0.867489 \\
\hline & Error & 41.2 & 12 & 3.4 & & \\
\hline
\end{tabular}

DF: degree of freedom; ${ }^{*} p<0.05$ statistically significant.

There are already some researches investigating the effect of electrical discharge on fibers. Yuan et al. [27] concluded that plasma improves the tensile strength and surface roughness, which leads to higher interfacial contact. In addition, during the treatment, it came to oxidation of fibers. Sinha and Panigrahi [28] observed increased hydrophobicity of jute fibers after plasma treatment, probably 
because of oxidation or decrease of phenolic and secondary alcoholic groups. Improved flexural strength of fibers occurred because of better adhesion between fibers and matrix. Bozaci et al. [29] and Karahan and Özdoğan [30] came to the conclusion that fibers have increased hydrophilicity, rougher surface and higher proportion of damaged fibers after plasma treatment.

Additional research is needed to reveal whether proposed mechanisms may be applicable to influence of HVED on fibers in cocoa shell.

\subsection{Grindability of Cocoa Shell}

The largest change in share of particles after HVED treatment was in the particle size ranges $0-50 \mu \mathrm{m}$ and $>315 \mu \mathrm{m}$ (Table 3). Untreated cocoa shell had the largest percentage of particles between 0 and $50 \mu \mathrm{m}$ and the smallest percentage of particles larger than $315 \mu \mathrm{m}$ compared to treated and control samples. Any treatment, either only in water or with HVED, has led to an increase in the share of particles with size greater than $315 \mu \mathrm{m}$ and a reduction in the share of particles with size less than $50 \mu \mathrm{m}$ which was proven by coefficient of correlation (Table 4). There is a relation between the smallest and the largest particles. Main effect analysis of variance showed that there was a statistically significant difference between different sample concentrations during treatment for particle sizes of 0-50 $\mu \mathrm{m}, 51-71 \mu \mathrm{m}$ and 72-100 $\mu \mathrm{m}$ (Table 2). In all treated samples decrease in the percentage of smaller particles and an increase in the percentage of larger particles was observed. The minimum change occurred in the sample 1.5\%, $30 \mathrm{~min}, 40 \mathrm{~Hz}$. Statistical analysis shows that there was a correlation between particle sizes and dietary fibers implying that difficulty to grind HVED treated cocoa shell can be caused by increased content of fibers. 
Table 3. Grindability of cocoa shell samples before and after the HVED treatment.

\begin{tabular}{|c|c|c|c|c|c|c|c|}
\hline Sample & $0-50 \mu \mathrm{m}(\%)$ & $51-71 \mu \mathrm{m}(\%)$ & $72-100 \mu \mathrm{m}(\%)$ & $101-125 \mu \mathrm{m}(\%)$ & $126-200 \mu \mathrm{m}(\%)$ & 201-315 $\mu \mathrm{m}(\%)$ & $>315 \mu \mathrm{m}(\%)$ \\
\hline UCS & 15.19 & 21.89 & 11.83 & 7.94 & 18.24 & 14.10 & 10.81 \\
\hline $1.5 \%, 15 \mathrm{~min}$ & 3.63 & 14.70 & 8.27 & 5.29 & 14.66 & 17.87 & 35.58 \\
\hline $1.5 \%, 30 \mathrm{~min}$ & 3.12 & 12.64 & 7.83 & 5.07 & 13.12 & 16.76 & 41.47 \\
\hline $1.5 \%, 45 \mathrm{~min}$ & 1.71 & 10.64 & 7.33 & 4.74 & 12.11 & 15.44 & 48.03 \\
\hline $1.5 \%, 15 \mathrm{~min}, 40 \mathrm{~Hz}$ & 5.64 & 13.78 & 7.42 & 5.52 & 13.62 & 17.42 & 36.61 \\
\hline $1.5 \%, 30 \mathrm{~min}, 40 \mathrm{~Hz}$ & 8.39 & 13.47 & 7.33 & 5.16 & 13.35 & 17.51 & 34.80 \\
\hline $1.5 \%, 45 \mathrm{~min}, 40 \mathrm{~Hz}$ & 3.67 & 13.67 & 7.42 & 5.15 & 12.65 & 16.94 & 40.50 \\
\hline $1.5 \%, 15 \mathrm{~min}, 80 \mathrm{~Hz}$ & 5.48 & 10.55 & 6.28 & 4.66 & 11.59 & 15.75 & 45.69 \\
\hline $1.5 \%, 30 \mathrm{~min}, 80 \mathrm{~Hz}$ & 2.64 & 11.71 & 8.59 & 5.50 & 13.33 & 16.75 & 41.48 \\
\hline $3.0 \%, 15 \mathrm{~min}$ & 3.52 & 9.98 & 7.22 & 4.64 & 11.72 & 15.36 & 47.56 \\
\hline $3.0 \%, 30 \mathrm{~min}$ & 2.28 & 9.19 & 9.33 & 5.77 & 13.10 & 16.40 & 43.93 \\
\hline $3.0 \%, 45 \mathrm{~min}$ & 2.16 & 9.26 & 10.98 & 6.40 & 15.05 & 17.31 & 38.84 \\
\hline $3.0 \%, 15 \mathrm{~min}, 40 \mathrm{~Hz}$ & 1.36 & 8.89 & 11.45 & 5.79 & 15.12 & 18.76 & 38.64 \\
\hline $3.0 \%, 30 \mathrm{~min}, 40 \mathrm{~Hz}$ & 0.64 & 4.04 & 11.23 & 7.40 & 15.23 & 18.69 & 42.77 \\
\hline $3.0 \%, 45 \mathrm{~min}, 40 \mathrm{~Hz}$ & 2.08 & 8.84 & 10.14 & 5.24 & 12.78 & 16.18 & 44.75 \\
\hline $3.0 \%, 15 \mathrm{~min}, 80 \mathrm{~Hz}$ & 1.50 & 11.73 & 10.83 & 6.07 & 15.48 & 19.18 & 35.20 \\
\hline $3.0 \%, 30 \mathrm{~min}, 80 \mathrm{~Hz}$ & 1.32 & 6.51 & 9.05 & 4.92 & 12.47 & 15.72 & 50.01 \\
\hline $3.0 \%, 45 \mathrm{~min}, 80 \mathrm{~Hz}$ & 3.07 & 11.41 & 7.46 & 4.41 & 11.17 & 15.14 & 47.33 \\
\hline
\end{tabular}

UCS: untreated cocoa shell. 
Table 4. Pearson's coefficients of correlation

\begin{tabular}{|c|c|c|c|c|c|c|c|c|c|c|c|c|c|c|}
\hline Variable & $0-50 \mu \mathrm{m}$ & $\begin{array}{c}51-71 \\
\mu \mathrm{m}\end{array}$ & $\begin{array}{c}72-100 \\
\mu \mathrm{m}\end{array}$ & $\begin{array}{c}101-125 \\
\mu \mathrm{m}\end{array}$ & $\begin{array}{c}126-200 \\
\mu \mathrm{m}\end{array}$ & $\begin{array}{c}201-315 \\
\mu \mathrm{m}\end{array}$ & $\begin{array}{l}>315 \\
\mu \mathrm{m}\end{array}$ & $\begin{array}{l}\text { WBC } \\
(\mathrm{g} / \mathrm{g})\end{array}$ & $\begin{array}{l}\text { OBC } \\
\text { (g/g) }\end{array}$ & $\begin{array}{l}\text { Insoluble } \\
\text { Fibers (\%) }\end{array}$ & $\begin{array}{c}\text { Soluble } \\
\text { Fibers (\%) }\end{array}$ & $\begin{array}{c}\text { Total Fibers } \\
(\%)\end{array}$ & $\begin{array}{l}\text { Tannin } \\
\text { (mg TA/g) }\end{array}$ & $\begin{array}{c}\text { Tannin } \\
(\%)\end{array}$ \\
\hline $0-50 \mu \mathrm{m}$ & 1.000 & & & & & & & & & & & & & \\
\hline $51-71 \mu \mathrm{m}$ & 0.839 & 1.000 & & & & & & & & & & & & \\
\hline $72-100 \mu \mathrm{m}$ & 0.006 & -0.083 & 1.000 & & & & & & & & & & & \\
\hline $101-125 \mu \mathrm{m}$ & 0.364 & 0.199 & 0.819 & 1.000 & & & & & & & & & & \\
\hline $126-200 \mu \mathrm{m}$ & 0.430 & 0.402 & 0.803 & 0.908 & 1.000 & & & & & & & & & \\
\hline $201-315 \mu \mathrm{m}$ & -0.456 & -0.329 & 0.312 & 0.210 & 0.303 & 1.000 & & & & & & & & \\
\hline$>315 \mu \mathrm{m}$ & -0.809 & -0.795 & -0.467 & -0.717 & -0.851 & 0.018 & 1.000 & & & & & & & \\
\hline WBC $(\mathrm{g} / \mathrm{g})$ & -0.252 & -0.106 & -0.473 & -0.422 & -0.391 & 0.096 & 0.349 & 1.000 & & & & & & \\
\hline OBC (g/g) & -0.827 & -0.838 & -0.103 & -0.479 & -0.600 & 0.114 & -0.862 & 0.233 & 1.000 & & & & & \\
\hline Insoluble fibers (\%) & -0.765 & -0.714 & -0.455 & -0.674 & -0.751 & 0.264 & 0.883 & 0.450 & 0.776 & 1.000 & & & & \\
\hline Soluble fibers (\%) & -0.519 & -0.351 & 0.098 & -0.179 & -0.023 & 0.582 & 0.268 & 0.306 & 0.334 & 0.334 & 1.000 & & & \\
\hline Total fibers (\%) & -0.791 & -0.723 & -0.425 & -0.666 & -0.722 & 0.318 & 0.875 & 0.464 & 0.780 & 0.994 & 0.435 & 1.000 & & \\
\hline Tannin (mg TA/g) & -0.244 & -0.154 & 0.058 & -0.089 & 0.035 & 0.357 & 0.097 & -0.118 & -0.100 & 0.123 & 0.065 & 0.127 & 1.000 & \\
\hline Tannin (\%) & -0.768 & -0.747 & 0.004 & -0.365 & -0.511 & 0.018 & 0.762 & -0.014 & 0.844 & 0.635 & 0.167 & 0.627 & 0.067 & 1.000 \\
\hline
\end{tabular}

Bold values were considered significant at $p<0.05$. 


\subsection{Water and Oil Binding Capacity}

$\mathrm{WBC}$ and $\mathrm{OBC}$ are important parameters for processing of food and any change in these properties influences production process. Water binding capacity (WBC) and oil binding capacity (OBC) of cocoa shell samples are shown in Figure 4. It is visible that the sample of untreated cocoa shell had the lowest WBC and OBC. Samples treated at a concentration of $1.5 \%$ had the higher WBC compared to samples treated at a concentration of 3.0\%. OBC showed the opposite trend, where samples treated at $3.0 \%$ had higher capacity for binding oil than samples treated at $1.5 \%$. The largest increases can be observed in samples treated for $45 \mathrm{~min}$ in water and with HVED. Statistical analysis showed that there was a statistically significant difference between tested concentrations and shearing time but treatment (with or without HVED) did not show statistical significance. All combinations of these effects have proven to be significant (Table 1).
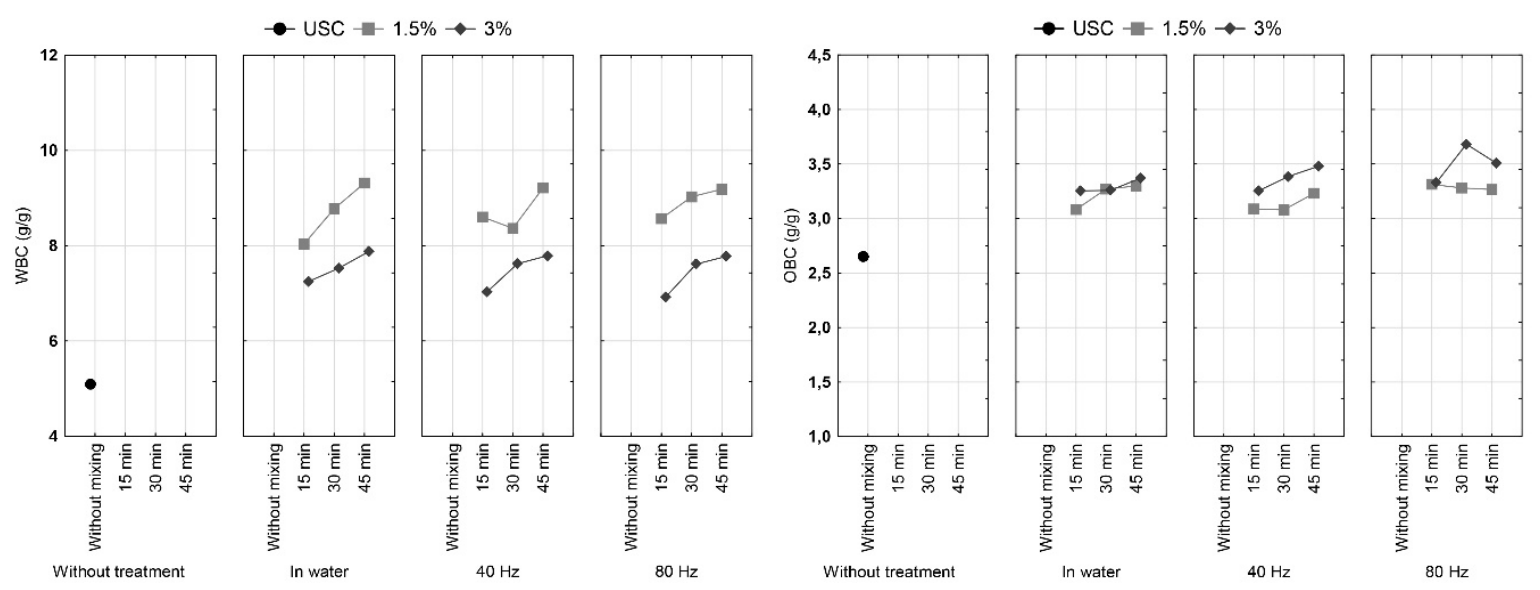

Figure 4. Oil and water binding capacity of cocoa shell before and after the HVED treatment.

According to Sangnark and Noomhorm [31], water and oil binding capacity are correlated to particle size. This research also revealed correlation of OBC with particle sizes (Table 4). Additionally, porosity, overall charge density and hydrophobic properties of fibers, all of which may be changed by HVED treatment, can greatly affect WBC and OBC [31,32]. This may also be substantiated by correlation of $\mathrm{OBC}$ with total fiber, insoluble fiber and tannin content in this research.

\subsection{FTIR-ATR}

The changes in chemical composition by HVED treatment were supported by FTIR-ATR analysis. All the treatments had similar trend so only representative spectra are shown in Figure 5.

In untreated cocoa shell $\mathrm{C}=\mathrm{O}$ stretching at $1737 \mathrm{~cm}^{-1}$ is presented only with a shoulder, and there is a peak at $1602.8 \mathrm{~cm}^{-1}$. After the treatment, a small peak appears at $1737 \mathrm{~cm}^{-1}$. Karahan and Özdoğan [30] ascribed this peak to ester groups of pectin. This is implying that increased content of soluble fibers may be linked to the appearance of this peak after the treatment. However, according to Günzler and Gremlich [33] and Grillo et al. [34], this is also C=O stretch in unconjugated esters, carboxylic acids, aldehydes and ketones.

$\mathrm{C}-\mathrm{H}$ asymmetric deformation vibrations in untreated shell are presented through a shoulder at $1410 \mathrm{~cm}^{-1}$, whereas after the treatments peak appears at $1431.3 \mathrm{~cm}^{-1}$.

In the untreated cocoa shell there is a peak at $1028.7 \mathrm{~cm}^{-1}$ with two shoulders at $1096 \mathrm{~cm}^{-1}$ and $1148 \mathrm{~cm}^{-1}$. Treatments did not change shoulder at $1096 \mathrm{~cm}^{-1}$, unlike the other one that has shifted to $1155 \mathrm{~cm}^{-1}$ (C-H deformation) and a small peak appears there. This is also close to peak $\left(1152 \mathrm{~cm}^{-1}\right)$ of C-O-C asymmetric vibration in carbohydrates and glucosides according to Grillo et al. [34]. 

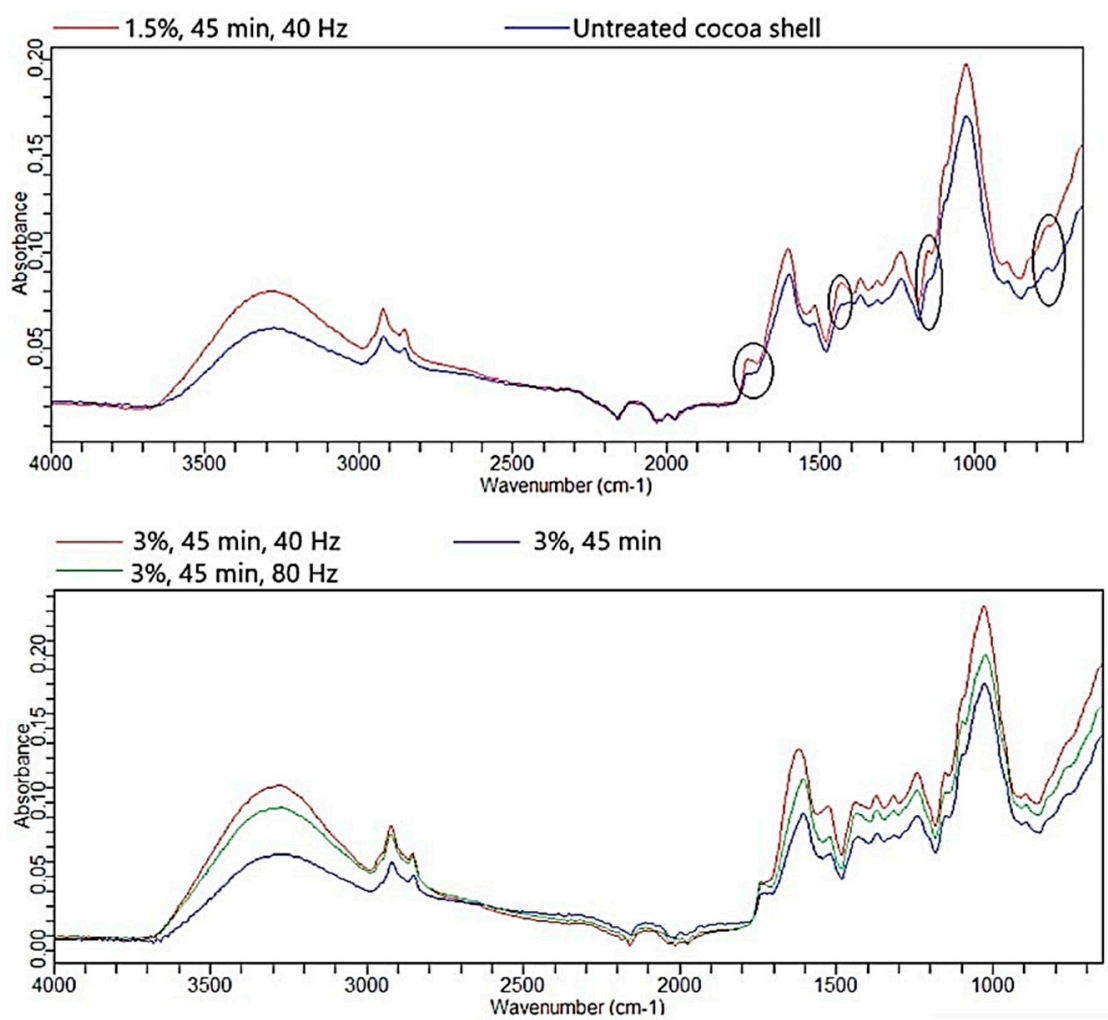

Figure 5. Representative Fourier transform infrared spectroscopy with attenuated total reflection (FTIR-ATR) spectra of cocoa shell before and after the HVED treatment.

Untreated cocoa shell had small peak at $760 \mathrm{~cm}^{-1}$ (ring deformation vibrations). Treatments transfers this to shoulder.

These changes in spectra are the result of combined effect of changes in fiber composition (insoluble:soluble ratio) and phenol changes. Bozaci et al. [29] also observed shift of the bands after cold plasma treatment of jute fibers. They assigned this to reaction of fibers with active species from the plasma.

\section{Conclusions}

In essence, our study showed influence of HVED on fiber properties (soluble, insoluble and total fiber content) and related physical properties-occurrence of larger particle size and increase of water and oil binding capacity. In addition, it has been established that changes in fiber properties correlate to changes in tannin content. It is evident that HVED has a significant influence on the physical and chemical characteristics of cocoa shells due to formation of large number of reactive species, including free radicals and ions, and the reactions occurring during treatment need to be further examined in order to see why such changes are taking place and to reveal actual mechanisms that are involved. Other chemical characteristics of the modified cocoa shell in future studies should be considered as well. In addition, the effect of change in physical and chemical properties of shell on its applicability in different foods needs to be examined because its properties such as grinding, taste, color etc. are the main reasons for its non-use in food production. This research is valuable for future applications of untreated and cocoa shells treated with HVED in the food industry.

Author Contributions: Conceptualization, V.B. and Đ.A.; methodology, I.F., M.K.; investigation, V.B., I.F., M.B., A.J.; writing—original draft preparation, V.B., Đ.A.; writing—review and editing, A.J., J.B., D.Š., B.M., Đ.A.; visualization, A.J., K.D., M.J.; funding acquisition, Đ.A. All authors have read and agreed to the published version of the manuscript.

Funding: This work has been supported in part by Croatian Science Foundation under the project UIP 2017-05-8709. 
Conflicts of Interest: The authors declare no conflicts of interest.

\section{References}

1. Arlorio, M.; Coisson, J.D.; Travaglia, F.; Varsaldi, F.; Miglio, G.; Lombardi, G.; Martelli, A. Antioxidant and biological activity of phenolic pigments from Theobroma cacao hulls extracted with supercritical $\mathrm{CO}_{2}$. Food Res. Int. 2005, 38, 1009-1014. [CrossRef]

2. Martin-Cabrejas, M.A.; Valiente, C.; Esteban, R.M.; Molla, E. Cocoa hull: A potential source of dietary fibre. J. Sci. Food Agric. 1994, 66, 307-311. [CrossRef]

3. Redgwell, R.; Trovatoa, V.; Merinat, S.; Curti, D.; Hedigera, S.; Manez, A. Dietary fibre in cocoa shell: Characterisation of component polysaccharides. Food Chem. 2003, 81, 103-112. [CrossRef]

4. Hernández-Hernández, C.; Viera-Alcaide, I.; Morales-Sillero, A.M.; Fernández-Bolaños, J.; Rodríguez-Gutiérrez, G. Bioactive compounds in Mexican genotypes of cocoa cotyledon and husk. Food Chem. 2017, 240, 831-839. [CrossRef] [PubMed]

5. Chun, K.S.; Husseinsyah, S.; Osman, H. Utilization of cocoa pod husk as filler in polypropylene biocomposites: Effect of maleated polypropylene. J. Compos. Mater. 2015, 28, 1507-1521. [CrossRef]

6. Panak Balentić, J.; Ačkar, Đ.; Jokić, S.; Jozinović, A.; Babić, J.; Miličević, B.; Šubarić, D.; Pavlović, N. Cocoa shell: A by-product with great potential for wide application. Molecules 2018, 23, 1404. [CrossRef] [PubMed]

7. Boussetta, N.; Turk, M.; De Taeye, C.; Larondelle, Y.; Lanoisellé, J.L.; Vorobiev, E. Effect of high voltage electrical discharges, heating and ethanol concentration on the extraction of total polyphenols and lignans from flaxseed cake. Ind. Crop. Prod. 2013, 49, 690-696. [CrossRef]

8. Yan, L.-G.; Deng, Y.; Ju, T.; Wu, K.; Xi, J. Continuous high voltage electrical discharge extraction of flavonoids from peanut shells based on "annular gap type" treatment chamber. Food Chem. 2018, 256, 350-357. [CrossRef]

9. Li, Z.; Fan, Y.; Xi, J. Recent advances in high voltage electric discharge extraction of bioactive ingredients from plant materials. Food Chem. 2019, 277, 246-260. [CrossRef]

10. Boussetta, N.; Vorobiev, E. Extraction of valuable biocompounds assisted by high voltage electrical discharges: A review. C. R. Chim. 2014, 17, 197-203. [CrossRef]

11. Barišić, V.; Jozinović, A.; Flanjak, I.; Šubarić, D.; Babić, J.; Miličević, B.; Doko, K.; Ačkar, Đ. Difficulties with Use of Cocoa Bean Shell in Food Production and High Voltage Electrical Discharge as a Possible Solution. Sustainability 2020, 12, 3981. [CrossRef]

12. Amorim, E.L.C.; Nascimento, J.E.; Monteiro, J.M.; Sobrinho, T.J.S.P.; Araújo, T.A.S.; Albuquerque, U.P. A simple and accurate procedure for the determination of tannin and flavonoid levels and some applications in ethnobotany and ethnopharmacology. Funct. Ecosyst. Communities 2008, 21, 88-94.

13. Singleton, V.L.; Orthofer, R.; Lamuela-Raventós, R.M. Analysis of total phenols and other oxidation substrates and antioxidants by means of Folin-Ciocalteu reagent. Methods Enzymol. 1999, 299, 152-178. [CrossRef]

14. AOAC 991.43. Total, soluble, and insoluble dietary fiber in foods: Enzymatic-gravimetric method, MES-TRIS buffer. In AOAC Official Methods, Suppl; Association of Official Analytical Chemists: Rockville, MD, USA, March 1995; Chapter 32; pp. 7-9.

15. AACC Method 88-04. In AACC Methods Manual, Revised Ed.; American Association of Cereal Chemists: St. Paul, MN, USA, 1983.

16. Barišić, V.; Flanjak, I.; Križić, I.; Jozinović, A.; Šubarić, D.; Babić, J.; Miličević, B.; Ačkar, Đ. Impact of high-voltage electric discharge treatment on cocoa shell phenolic components and methylxanthines. J. Food Process Eng. 2020, 43, e13057. [CrossRef]

17. Jokić, S.; Pavlović, N.; Jozinović, A.; Ačkar, Đ.; Babić, J.; Šubarić, D. High-voltage electric discharge extraction of bioactive compounds from the cocoa bean shell. Chem. Biochem. Eng. Q. 2019, 33, 271-280. [CrossRef]

18. Delsart, C.; Grimi, N.; Boussetta, N.; Miot Sertier, C.; Ghidossi, R.; Vorobiev, E.; Mietton Peuchot, M. Impact of pulsed-electric field and high-voltage electrical discharges on red wine microbial stabilization and quality characteristics. J. Appl. Microbiol. 2015, 120, 152-164. [CrossRef]

19. Lukić, K.; Vukušić, T.; Tomašević, M.; Ćurko, N.; Gracin, L.; Kovačević Ganić, K. The impact of high voltage electrical discharge plasma on the chromatic characteristics and phenolic composition of red and white wines. Innov. Food Sci. Emerg. Technol. 2019, 53, 70-77. [CrossRef] 
20. Guyot, S.; Bernillon, S.; Poupard, P.; Renard, M.G.C.C. Multiplicity of phenolic oxidation products in apple juices and ciders, from synthetic medium to commercial products. In Recent Advances in Polyphenol Research; Daayf, F., Lattanzio, V., Eds.; Wiley-Blackwell: Hoboken, NJ, USA, 2008; pp. 278-293.

21. Lecumberri, E.; Mateos, R.; Izquierdo-Pulido, M.; Rupérez, P.; Goya, L.; Bravo, L. Dietary fibre composition, antioxidant capacity and physico-chemical properties of a fibre-rich product from cocoa (Theobroma cacao L.). Food Chem. 2007, 104, 948-954. [CrossRef]

22. Bravo, L.; Grades, N.; Saura-Calixto, F. Composition and potential uses of mesquite pods (Prosopis pallida L): Comparison with carob pods (Ceratonia siliqua L). J. Sci. Food Agric. 1994, 65, 303-306. [CrossRef]

23. Saura-Calixto, F. Dietary fibre complex in a sample rich in condensed tannins and uronic acids. Food Chem. 1987, 23, 95-103. [CrossRef]

24. Perez, E.; Mendez, A.; Leon, M.; Hernandez, G.; Sivoli, L. Proximal composition and the nutritional and functional properties of cococa by-products (pods and husks) for their use in the food industry. In Chocolate-Cocoa Byproducts Technology, Rheology, Styling, and Nutrition; Perez Sira, E., Ed.; Nova: New York, NY, USA, 2015; pp. 219-230.

25. Barišić, V.; Flanjak, I.; Tot, A.; Budeč, M.; Benšić, M.; Jozinović, A.; Babić, J.; Šubarić, D.; Miličević, B.; Ačkar, Đ. 5-hydroxymethylfurfural and acrylamide content of cocoa shell treated with high voltage electrical discharge. Food Cont. 2020, 107043. [CrossRef]

26. Ozdal, T.; Capanoglu, E.; Altay, F. A review on protein-phenolic interactions and associated changes. Food Res. Int. 2013, 51, 954-970. [CrossRef]

27. Yuan, X.; Jayaraman, K.; Bhattacharyya, D. Effects of plasma treatment in enhancing the performance of woodfibre-polypropylene composites. Compos. Part A Appl. Sci. Manuf. 2004, 35, 1363-1374. [CrossRef]

28. Sinha, E.; Panigrahi, S. Effect of plasma treatment on structure, wettability of jute fiber and flexural strength of its composite. J. Compos. Mater. 2009, 43, 1791-1802. [CrossRef]

29. Bozaci, E.; Sever, K.; Demir, A.; Seki, Y.; Sarikanat, M.; Ozdogan, E. Effect of the atmospheric plasma treatment parameters on surface and mechanical properties of jute fabric. Fibers Polym. 2009, 10, 781-786. [CrossRef]

30. Karahan, H.A.; Özdoğan, E. Improvements of surface functionality of cotton fibers by atmospheric plasma treatment. Fibers Polym. 2008, 9, 21-26. [CrossRef]

31. Sangnark, A.; Noomhorm, A. Effect of dietary fibre from sugarcane bagasse and sucrose esteron doughand bread properties. LWT 2004, 37, 697-704. [CrossRef]

32. Ulbrich, M.; Flöter, E. Impact of high pressure homogenization modification of a cellulose based fiber product on water binding properties. Food Hydrocoll. 2014, 41, 281-289. [CrossRef]

33. Günzler, H.; Gremlich, H. IR-Spektroskopie: Eine Einführung, 4th ed.; WILEY-VCH GmbH \& Co. KGaA: Weinheim, Germany, 2003.

34. Grillo, G.; Boffa, L.; Binello, A.; Mantegna, S.; Cravotto, G.; Chemat, F.; Dizhbite, T.; Lauberte, L.; Telysheva, G. Analytical dataset of Ecuadorian cocoa shells and beans. Data Brief. 2019, 22, 56-64. [CrossRef] [PubMed] 